\title{
O MAL-ENTENDIDO DA DEMOCRACIA Sergio Buarque de Hollanda, Raizes do Brasil, 1936*
}

\section{Leopoldo Waizbort}

\section{Preâmbulo}

Ler Raízes do Brasil na contracorrente pode ser válido, com vistas a eriçar alguns pontos de interesse para o pensamento político e social de seu autor e de sua circunstância. ${ }^{1}$ Mas isso exige delinear, em-

* Este texto foi apresentado, de modo condensado, em conferência no Instituto de Estudos Brasileiros da USP em 17 de novembro de 2008 e no Seminário "O Brasil (não é) para principiantes" do GT "Pensamento Social no Brasil" da Anpocs, em 17 de março de 2009. Agradeço aos convites dos organizadores dos dois eventos, assim como às críticas e sugestóes dos participantes e de outros/as colegas, que posteriormente puderam ler e comentar o texto. A responsabilidade pelo texto é entretanto exclusivamente minha. Neste artigo, a partir de agora atualizo a ortografia de Raizes do Brasil.

Artigo recebido em agosto/2010

Aprovado em fevereiro/2011 bora do modo o mais esquemático, a corrente que conduz majoritariamente as leituras dessa caudalosa interpretação do Brasil.

No caso de Raízes do Brasil, essa tarefa é em grande medida facilitada pelo prefácio - sem esse nome - que Antonio Candido escreveu para o livro em 1967 (portanto, em um momento tenso da história nacional) e que, desde então, é reproduzido nas reediçôes, como um movimento de abertura que acaba sendo lido quase como se fosse um capítulo inicial do livro, não raro acabando por sugerir e direcionar a compreensão do que lhe sucede.

Isso ocorre por variadas razões. A primeira é a conjugação característica de Antonio Candido em agudeza ímpar e clareza de exposição, que no caso da leitura proposta de Raízes do Brasil tem o papel adicional de atenuar as muitas ambiguidades do texto e firmar o rumo de uma interpretação mais plana, que diminui suas tensôes. Em segundo lugar, a forma adotada do prefácio-introdução, de 
fato de caráter introdutório, percorrendo o livro capítulo a capítulo e apontando, a cada passo, quais são os temas relevantes, qual o encaminhamento a eles dado pelo autor e, por fim, qual o sentido geral do argumento, quando não clara e integralmente desenvolvido ou explicitado por Sérgio Buarque de Holanda. Resulta dessa visada um autor claramente progressista, engajado na ruína das antigas oligarquias e no "advento de novas camadas" (Candido, 2006 [1967], p. 248). Nesse ponto particular, entretanto, Antonio Candido parece não ter sido suficientemente claro, chegando mesmo a, posteriormente, procurar desenvolver e clarificar essa ideia, ao argumentar que encontramos, em Raizes do Brasil, um "radicalismo potencial das classes médias" comprometido com o "povo" (Candido, 2006 [1986], p. 252). ${ }^{2}$

A leitura de Antonio Candido, como disse norteadora, enraíza retrospectivamente o livro em um contexto intelectual e social e busca, nesse enraizamento, dissipar ambiguidades de natureza sobretudo política, convertendo o livro em um pioneiro do radicalismo democrático.

No polo oposto a uma leitura como a de Antonio Candido, encontramos leituras que operam uma desistorização do texto, lançando mão de procedimentos vários para desenraizar o texto de seu contexto. Um exemplo extremo, e por isso muito ilustrativo, é uma argumentação que justifica as ambiguidades do texto por meio de uma metaforologia, operando um esvaziamento do político às custas da metáfora ou, por outra, utiliza-se do argumento da metáfora para subtrair o argumento político. ${ }^{3}$ Uma tal consideração do texto sob a perspectiva metafórica dilui seu sentido histórico - seu enraizamento em um contexto social e histórico determinado - e, no limite, a sua legibilidade.

A essas duas leituras - tomadas aqui mui rapidamente e apenas a título de ilustração - bastaria apenas lembrar o desconforto e o distanciamento crítico do próprio Sérgio Buarque diante de seu livro de estreia, escrito em algum momento entre a Revolução de 1930 e o advento do Estado Novo. ${ }^{4}$ Desconforto grande e perturbador, a ponto de exigir um remanejamento substantivo do texto para a segunda edição, de 1948 - portanto em pleno período de "redemocratização" -, remanejamento que tem como principal questão melhor solucionar (ou embaralhar) a perspectiva política contida na argumentação original. Também aqui é possível aquilatar a importância funcional do "prefácio" de Antonio Candido, que oferece uma moldura apascentadora para o livro.

Tudo isso apenas a título de introdução, no sentido de sugerir rudemente algo do contexto, da pretensão e dos limites do que argumentarei a seguir. Antes contudo de formular o argumento principal, é preciso que tenhamos clareza com relação ao enquadramento mais geral do livro publicado em 1936. Não o enquadramento contextual local, sem dúvida alguma absolutamente central para uma ponderação informada e justa do livro, mas que não é o problema que pretendo abordar. ${ }^{5}$ Interessa assinalar apenas o enquadramento mais amplo da concepção cognitiva, que ordenava a tentativa de Sérgio em sua interpretação.

A matriz que fornece o enquadramento mais geral para Sérgio Buarque, em Raízes do Brasil, é uma perspectiva de análise que procura conjugar estrutura de personalidade e estrutura social. O segredo, claro está, é o "conjugar"; uma questão central - que, contudo, talvez não faculte uma resposta definitiva - é ganhar clareza com respeito às relações que se estabelecem entre estrutura da personalidade e da sociedade.

Tendo por base esse nexo, o problema desdobra-se na compreensão das transformações da estrutura da personalidade e das transformações da estrutura da sociedade, o que significa adentrar, em sentido enfático, em uma discussão histórico-sociológica (pois que modelada e modulada em um enquadramento sociológico, que busca fundamentação em argumento e desenvolvimento históricos).

Por fim, a partir do nexo "transformaçōes da estrutura da personalidade e transformaçōes da estrutura da sociedade", chegamos ao ponto: compreender como ambas as transformaçóes estão relacionadas. Ademais, considerando que falamos de duas ordens distintas, embora articuladas, é preciso ter em conta a dinâmica específica de cada uma delas, dado que não estão necessariamente encompassadas - dando margem portanto a descontinuidades, a defasagens, a ritmos diferenciados de transformação, a simultaneidades do que não é simultâneo. 
Argumento, dessarte, que Raizes do Brasil depende, em sua arquitetura cognitiva, desse pressuposto ou enfoque. A partir dele, Sérgio Buarque desenvolve o seu argumento histórico-sociológico, pois indagar pela natureza da articulação/relação entre as transformaçóes da estrutura da personalidade e as transformaçōes da estrutura da sociedade é justamente uma das maneiras de sugerir a passagem de uma dimensão mais propriamente histórica para uma dimensão mais propriamente sociológica.

Isso tem como consequência, ademais, indagar pelas temporalidades específicas e pelas modalidades próprias a esses âmbitos de transformaçōes. A resposta a essas indagações é de natureza eminentemente histórica e constitui a estrutura factual da interpretação oferecida em Raizes do Brasil.

Um tal desenvolvimento e o intuito de oferecer uma investigação que conjuga e articula (transformações da) estrutura da personalidade e (transformaçōes da) estrutura da sociedade - psicogênese e sociogênese, para formular em jargão e de modo mais sucinto - é, por fim, o que permite situar Sérgio Buarque no âmbito de um contexto de discussão alemão, do qual se aproximou definitivamente durante o tempo em que esteve na Alemanha. Pois, no período que vai da virada para o século XX até o início do período nacional-socialista na Alemanha, a discussão acerca dos nexos de psico e sociogênese é um dos núcleos fortes em torno do qual gravitavam os debates acerca da interpretação histórico-cultural-social, debate esse difuso por toda a plêiade das humanidades.

Especialmente a sociologia de então procurou desenvolver esse problema, que pode ser facilmente rastreado no arco que vai de Georg Simmel, Max Weber, Ernst Troeltsch e Werner Sombart a Hans Freyer, Karl Mannheim e Norbert Elias, para nomear apenas alguns. Em Raizes do Brasil encontramos Sérgio Buarque trabalhando em chave similar: determinação mútua e de dupla mão da estrutura da personalidade pela estrutura da sociedade e da estrutura da sociedade pela estrutura da personalidade. Mas essa determinação mútua é vista em meio a um processo de transformação e mudança, e a questão é então também perceber, a cada momento, em que medida um dos lados é mais intensamente o motor do processo, ou o freia, e como ambos os vetores interagem e/ou conflitam.
Uma tarefa da crítica é ponderar como isso ocorre na análise de Sérgio Buarque. Creio que podemos, grosso modo, distinguir alguns elementos a respeito. Assim, que "Corpo e alma do Brasil" - o ensaio que Sérgio publica um ano antes de Raizes do Brasil e que é composto de extratos do livro posterior - tivesse como subtítulo "Ensaio de psicologia social", é revelador para definir os pesos e as ênfases dados pelo autor à estrutura da personalidade e à estrutura da sociedade: ele assume então uma perspectiva que parte da estrutura da personalidade. Ao tratar do "caráter nacional", fundamenta-o em um "fundo emocional" (Holanda, 2006 [1935a], p. 399). Há, ao que parece, uma precedência da dimensão psicogenética.

Essa precedência poderia ser explicada pelo próprio argumento desenvolvido, a saber, que privilegiamos o individual ao coletivo: Sérgio indica como "o individual consegue manter sem dano a sua supremacia sobre o social” (Idem, p. 400). Já no livro de 1936, essa precedência psicogenética talvez seja obliterada pelo ímpeto sociogenético, de sorte que teríamos um arranjo mais equilibrado, por assim dizer, dos dois vetores. Voltarei a esse ponto mais tarde, a partir de outro ângulo. Como quer que seja, este é um problema central para a ponderação justa do livro, mas que não pretendo resolver. Interessa-me apenas sugerir esse enquadramento mais amplo para que possamos passar ao tópico principal.

\section{$\mathrm{O}$ problema e o argumento}

Introduzo diretamente o problema, nas palavras do próprio autor, para maior ênfase e imediaticidade:

A democracia no Brasil foi sempre um lamentável mal-entendido (Hollanda, 1936, p. 122, cf. também p. 153).

A ausência de verdadeiros partidos não é entre nós, como há quem suponha singelamente, a causa de nossa inadaptação a um regime legitimamente democrático, mas antes uma consequência dessa inadaptação" (Idem, p. 151) 
Todo o pensamento liberal-democrático pode resumir-se na frase célebre de Bentham: "A maior felicidade para o maior número". Não é difícil perceber-se que essa ideia está em contraste direto com qualquer forma de convívio humano de base emocional (Idem, p. 156).

As três passagens formam evidentemente sistema e estão bem afinadas entre si, como outras mais, que seriam aqui redundantes. Elas formulam uma tese importante de Sérgio Buarque, que o mais das vezes tem sido enevoada nas leituras do livro. Embora aqui desconectadas de seu contexto argumentativo, as passagens formulam uma configuração significativa daquela articulação de sociogênese e psicogênese, importante sobretudo na revelação do posicionamento político (amálgama de diagnóstico e prognóstico), resultante da análise histórico-sociológica, que lastreia Raizes do Brasil.

Há uma incompatibilidade de raiz entre a dimensão psicogenética que é posta a descoberto por Sérgio Buarque e uma estrutura social de caráter democrático. Dessarte, a imposição de uma tal estrutura aparece em total descompasso e inadequação com a psicogênese - no trecho, esta diz respeito àquela forma de convívio humano de base emocional, amplamente tematizada ao longo de Raizes do Brasil. Nesse sentido, haveria uma base psicogenética que torna inadequada e imprópria uma determinada formação sociogenética; esta seria, no caso em pauta, uma estrutura estranha, uma aberração, imposta e não gestada organicamente e afim ao domínio psicogenético. Essa vetorialização divergente de estrutura da personalidade e estrutura social tem como resultado tamanha tensão, que necessariamente um dos vetores há de sucumbir ao outro; no caso, uma tal estrutura da sociedade sucumbe à estrutura da personalidade: a democracia é, entre nós, necessariamente um mal-entendido.

Parece-me evidente que, para Sérgio, há uma incompatibilidade de raiz entre o que ele entende ser o "temperamento nacional" e a "espontaneidade nacional" (cf. Idem, pp. 154, 144, 151), de um lado, e as formas democráticas ou liberal-democráticas, de outro.

Isso não significa, entretanto, que Sérgio se alinhe seja à ditadura, seja à anarquia. Ele parece identificar-se com um regime oligárquico, tingido por lideranças pessoais (talvez populistas) (cf. Idem, pp. 152-153). Ouçamo-lo em um passo de especial relevo:

Entre nós, já o dissemos, o personalismo é uma noção positiva - talvez a única verdadeiramente positiva que conhecemos. Ao seu lado todos os lemas da democracia liberal são conceitos puramente decorativos, sem raízes profundas na realidade. Isso explica bem como nos países latino-americanos, onde o personalismo - ou mesmo a oligarquia, que é o prolongamento do personalismo no espaço e no tempo - conseguiu abolir as resistências da demagogia liberal, acordando os instintos e os sentimentos mais vivos do povo, tenha assegurado, com isso, uma estabilidade política que de outro modo não teria sido possível. A formação de elites de governantes em torno de personalidades prestigiosas tem sido, ao menos por enquanto, o principio político mais fecundo em nossa América (Idem, p. 152 , grifos meus). ${ }^{6}$

Há, portanto, em formulação inequívoca, uma defesa da oligarquia (mas não necessariamente plutocracia ou aristocracia). Essa defesa baseia-se em uma análise dos fundamentos do "povo", de sua "alma" (cf. Idem, pp. 156 passim). Mas "povo", aqui, no sentido de coletivo genérico, jamais como um estrato social particularizado. ${ }^{7}$

Note-se que a elite ou oligarquia de que fala Sérgio Buarque seria uma espécie de decantação da alma popular, que saberia expressar. E sabe exprimi-la por seu caráter personalista, ou seja, por concretizar um traço de caráter constitutivo do povo - com efeito, o traço por excelência (cf. Idem, p. 101) ${ }^{8}$ Creio que é essa a "mensagem política" de Sérgio Buarque em 1936 (a expressão é de Antonio Candido, mas a utilizo em sentido divergente).

Por ora, gostaria ainda de destacar alguns dos termos por mim grifados na citação acima, todos eles bem conhecidos da crítica cultural e política de caráter conservador e antiliberal: o verdadeiro topos da elucubração bastarda, daquilo que é ou está desconectado da realidade, e a sua contraface, o primado da "realidade" como instância da verdade;" 
a crítica explícita ao liberalismo; ${ }^{10}$ a compreensão romântica de "povo" como coletivo totalizante e morfologicamente indefinido e indefinível; o recurso essencialista aos instintos e sentimentos como instâncias geradoras de autenticidade e verdade e, por fim, a noção mesma de elite como protagonista política por excelência. Vocabulário e ideário mobilizados por Sérgio revelam, em meu entender, sua afinidade com a crítica, de caráter conservador e antidemocrático, ao liberalismo (e, nem é preciso dizer, às outras tendências ainda mais à esquerda do liberalismo). Avançando nessa direção, ele chega a ser bastante consequente ao conjugar todos esses elementos, cuja aliança não era incomum no pensamento conservador radical de seu tempo.

Em meu juízo, essa argumentação é reiterada de modo significativo na abertura do célebre capítulo sobre "Nossa revolução". Pois aquela oligarquia e aquele elitismo estão em harmonia com o Friedrich Nietzsche citado em epígrafe ao capítulo final de Raizes do Brasil:

Um povo perece, quando confunde seu dever com o conceito de dever em geral (Nietzsche, 1988 [1888a], p. 117; Hollanda, 1936, p. 133).

Epígrafe essa retirada das edições posteriores do livro, e que destacava um verdadeiro topos do pensamento nitezscheano: a assunção de um dever abstrato e geral às custas de um dever próprio, individual, específico, concreto - vital. O sentido do recurso a Nietzsche torna-se mais claro se lido no contexto da argumentação precedente. $\mathrm{O}$ conceito de dever é aquele valor alienígena, estranho ao povo - no caso em pauta, a democracia. O verdadeiro triunfo de um povo está no reconhecimento e na assunção de seus instintos e sentimentos os mais vivos; o povo triunfa quando segue sua própria natureza, no caso o "personalismo".

Não é fortuito, portanto, que essa epígrafe tenha sido expurgada de Raizes do Brasil a partir de sua segunda edição. E mesmo na primeira, citada em alemão, certamente permaneceu obscura para grande parte dos leitores de então, e desconhecida para os posteriores. Por essa razão, vale a pena uma pequena interpolação sobre o sentido dessa epígrafe, extraída de $O$ anticristo. Diz Nietzsche:
Ainda uma palavra contra Kant como moralista. Uma virtude precisa ser nossa invenção, nossa defesa e necessidade a mais pessoal: em qualquer outro sentido ela é simplesmente um perigo. Aquilo que não condiciona a nossa vida, prejudica-a: uma virtude oriunda meramente de um sentimento de respeito diante do conceito de "virtude", como queria Kant, é prejudicial. A "virtude", o "dever", o "bom em si”, o bom com o caráter da impessoalidade e da validade universal delírios nos quais se exprimem o declínio, o enfraquecimento final da vida, o chinesismo königsberguiano. As mais profundas leis da conservação e do crescimento exigem o inverso: que cada um invente sua virtude, seu imperativo categórico. Um povo perece, quando confunde seu dever com o conceito de dever em geral. Nada arruína mais profundamente, mais intimamente do que todo dever "impessoal”, todo sacrifício em face do moloch da abstração (Nietzsche, 1988 [1888a], p. 117, grifos meus). ${ }^{11}$

É fascinante perceber como Sérgio Buarque alinha-se à crítica nietzscheana do dever abstrato, alienígena, estranho à vida, que não brota dos instintos e dos sentimentos! Ele impregnou-se dessa ideia, da crítica à generalidade abstrata, e encarna apaixonado a apologia nietzscheana: cabe ao povo descobrir e realizar a sua virtude própria, que somente pode aflorar da sua vida. Essa vida, Sérgio procurou, ao longo do livro, indicar, e concentrou-a naquela discussão sobre psico e sociogênese.

Assim, contextualizando a argumentação: a democracia é um perigo, pois é hostil à vida. Já que ela não condiciona a vida do povo, prejudica-a. $\mathrm{O}$ imperativo categórico do nosso povo é o nosso personalismo. É ele que deve pautar nossa organização política e social. Ao invés de negá-lo, contestá-lo ou ignorá-lo, devemos afirmá-lo, nele mergulhar e nele encontrar o princípio que oriente a nossa cristalização social, cultural e política.

Nosso autor parece compartilhar por inteiro o argumento de Nietzsche, compreendendo inclusive a sua virada rumo ao coletivo, ou seja, não o referindo ao indivíduo, mas sim à individualidade so- 
cial: o povo (no sentido já aventado). O imperativo categórico do nosso povo? Nosso personalismo.

Ele é a nossa virtude, nossa força positiva par excellence. Em contrapartida, o sacrifício ao moloch da abstração é a imposição da democracia (o dever impessoal de Nietzsche, o conceito de dever em geral); basta lembrar que nossa "aversão ao ritualismo" (Hollanda, 1936, p. 107) não poderá combinar jamais com o ritualismo que a instituição democrática exige.

Além disso, há que lembrar, para formular melhor mais adiante, o papel fundamental que a noção de "vida" desempenha aqui, pois ela reverbera com amplitude e peso em Sérgio Buarque e cimenta-o, uma vez mais, àquele pensamento conservador radical.

Disse anteriormente, pondo em destaque o argumento de Sérgio, que há em Raízes do Brasil uma defesa da oligarquia, mas é importante firmar que uma tal defesa não concorda necessariamente com a plutocracia. Com efeito, Sérgio condena a República justamente por ter instituído uma plutocracia.

A República, que não criou nenhum patriciado, mas apenas uma plutocracia, ignorou-os [os velhos senhores rurais] por completo. Daí o melancólico silêncio a que ficou reduzida a casta de homens que no tempo do Império dirigia e animava as instituições, assegurando ao conjunto nacional uma certa solidez orgânica, que nunca mais foi restaurada (Idem, p. 141)

Há aqui uma espécie de nostalgia do Império, no reconhecimento de que aquela situação ou cristalização histórica era mais afim à alma nacional. ${ }^{12}$ $\mathrm{Na}$ página seguinte, Sérgio Buarque desenvolve o argumento de que o Império havia concretizado um Estado forte, de que carecemos, sem cair no despotismo, que recusa. Fica sugerido, desse modo, um Estado oligárquico baseado no princípio fundamental que compõe a alma do povo, o personalismo. Ou seja, que retira sua força desse personalismo e que por meio dele é capaz de articular a nação como organismo. ${ }^{13}$ Daí um ar de respeito pelo Poder Moderador, que coaduna com traços de nostalgia do Império (cf. Idem, pp. 141-143, assim como p. 131).
Por outro lado, é consequente a sua recusa da tirania, da ditadura e do caudilhismo, que em seu entender são negações do liberalismo que se fazem de "dentro do mesmo âmbito" (cf. Idem, pp. 149 e 152). Isso reforça, portanto, o argumento de que a postura de Sérgio é antiliberal em amplo espectro; seu objetivo é nada mais e nada menos do que uma "superação da doutrina democrática" (Idem, pp. 149-150). Essa superação buscaria seu fundamento naquela conexão de psico e sociogênese, e concretizaria a seu modo o programa nietzscheano. Isso tudo revela que se trata mesmo de uma crítica conservadora radical, de caráter quase revolucionário.

A questão da tirania aparece modulada em um passo por várias razões interessante: "Com a cordialidade, a bondade, não se criam os bons princípios. É necessário um elemento normativo, sólido, inato na alma do povo, ou implantado pela tirania para que possa haver cristalização social" (Idem, pp. 156-157).

A essa altura, Sérgio justifica seu argumento reportando-se novamente a Friedrich Nietzsche, nomeadamente a uma passagem de Crepúsculo dos deuses, cujo parágrafo intitulado "Crítica da modernidade" desenvolve, entre outras coisas, uma crítica ao casamento fundado no amor, em favor de um impulso mais profundo, este sim capaz de fundar uma instituição: no caso específico do casamento, trata-se tanto do impulso sexual como do impulso à propriedade, e ambos são na verdade modulações de um outro impulso, mais profundo e matricial: o impulso à dominação. $\mathrm{O}$ argumento de Nietzsche é que esse impulso à dominação está na base de formas de organização mais amplas, como a família e a sociedade (cf. Nietzsche, 1988 [1888b], p. 142).

Trocando em miúdos: se voltarmos ao argumento de Sérgio Buarque, isso significa que seria preciso encontrar na alma do povo esse impulso à dominação, que seria a única forma de estabelecimento de instituição enraizada no nosso temperamento nacional, no nosso povo. Por conseguinte, "a consolidação e a estabilização de um organismo social e nacional”, como diz Sérgio, depende de um elemento, que é aquilo que Nietzsche entendia estar na base das instituiçôes, a autoridade (cf. Idem, p. 141). Portanto, trata-se 
de encontrar, na alma do povo, um princípio de autoridade e dominação, que poderia dar forma e duração à sociedade.

Uma alternativa a isso, não obstante, existe e é reconhecida: se o impulso à dominação não é encontrado na alma do povo, ele pode ser inculcado por meio da tirania, que embora não seja a solução ideal, está longe de ser demonizada, como propaga, no entender de Sérgio, a doutrina liberal (cf. Hollanda, 1936, p. 157).

A solução preconizada por Sérgio Buarque, portanto, é de um princípio de autoridade fundado no personalismo. Suas concretizações são a oligarquia e, caso esta não tenha força suficiente, a tirania. Assim seria possível erigir a cristalização social da nação, expressão máxima (e necessária), em termos políticos e sociais, da alma do povo.

Além desse argumento propriamente político, é importante ressaltar como aquele nexo de sociogênese e psicogênese está incrustado nesse enfoque; o andamento da análise e a construção do argumento dele dependem.

Ademais, um problema importante a investigar é como Sérgio Buarque elabora estática e dinâmica nos âmbitos das estruturas de personalidade e da sociedade. A "nossa revolução" significa um processo de transformação de média duração na estrutura da sociedade. Ocorre, concomitantemente, uma transformação na estrutura da personalidade? $\mathrm{Ou}$ seria antes uma transformação na estrutura da personalidade, que viria ocorrendo ao longo dos tempos, que permitiria a emergência de uma estrutura social renovada?

São questôes que não encontram resposta simples no plano da argumentação do livro. Há, em alguma medida, uma transformação na estrutura da personalidade, mas o problema é, por assim dizer, a sua intensidade e em que medida ela é forte o suficiente para imprimir uma marca na estrutura social. Ou seja, como se dá a confluência de psico e sociogênese nesse andamento complexo e nebuloso. Em certa medida, a "personalidade" permanece estável, mas estabilidade não significa que, em um processo de média e longa duração, não haja alteração gradual. Transformações lentas e graduais, gestadas e maturadas na alma do povo: esse parece ser o caminho possível para uma transformação social.

\section{Guarnecendo o argumento}

Dadas as leituras prevalecentes de Raízes do Brasil, feitas o mais das vezes com base no texto revisto, creio ser importante fundamentar textualmente a linha de argumentação aqui desenvolvida, com vistas a legitimar, com mais materiais, a pertinência e a justeza do argumento.

Quase todas as passagens citadas até agora de Raizes do Brasil foram retiradas dos dois capítulos finais do livro. Com razão, pois nesse momento final da argumentação o problema surge com maior clareza, em função do direcionamento do livro para o tempo presente. Entretanto, seria equivocado supor que essas afirmações são incongruentes com o curso geral do argumento. Ao contrário, é significativo constatar como, ao longo do livro, Sérgio Buarque destaca aspectos relevantes para a fundamentação da tese política geral que aparece com maior ênfase nos capítulos finais e que procurei evidenciar. Nesse sentido, pode-se mesmo argumentar que ele vai guarnecendo gradualmente e com matizes e modulaçôes esse raciocínio que, presente desde o início, aflora pleno e maduro nos capítulos finais.

Destarte, já no capítulo inicial encontramos o diagnóstico da "nossa desordem" e da "nossa anarquia” (Hollanda, 1936, p. 6), ${ }^{14}$ que somente podem ser domadas por força externa e impositiva. Se de um lado o indivíduo autárquico e a personalidade individual marcada e o mais das vezes exaltada predominam entre os povos ibéricos, ambos encontram uma contraface paradoxal na propensão à obediência, que seria, para os ibéricos, a "virtude suprema entre todas", e por essa razão tem ela "sido até agora para eles o único princípio político verdadeiramente forte" (Idem, p. 14) Isso porque o "princípio da hierarquia" (Idem, p. 9) nos é estranho, dado não emergir daquelas camadas profundas do povo: não é autêntico, nem vital. Com efeito, aqui Sérgio parafraseia um argumento nietzscheano, ao afirmar que o "princípio formador da sociedade" é de fato uma "força inimiga, inimiga do mundo e da vida" (Idem, pp. 8-9).

Uma tal argumentação permite a Sérgio atar a dimensão pessoal à dimensão coletiva, pois que a virtude, encarnada no indivíduo, é alçada ao do- 
mínio do social e político. Por outras palavras, a política assenta na virtude, que é pessoal; entretanto, não se trata de virtude ou princípio abstratos, que se concretizariam melhor ou pior nos átomos sociais, e sim de um princípio concreto, incrustado no indivíduo, do qual parte. Creio que ele autorizaria denominá-la - permanecendo no âmbito de sua terminologia vitalista - uma "força viva". A obediência é a contraface de uma vontade de poder, um instinto de domínio, um "impulso à dominação", como diria aquele Nietzsche ao qual Sérgio faz referência e reverência. Trata-se, nos termos de Sérgio, da "autarquia do indivíduo", da "exaltação extrema da personalidade" (Idem, p. 14), por meio das quais a obediência preencheria a dimensão social e coletiva possível de uma estrutura da personalidade em tudo hostil ao que tolhe ou ultrapassa a mencionada autarquia, ao que se contrapõe ao arbítrio individual.

Esse raciocínio é convertido imediatamente por Sérgio em agudo diagnóstico do presente, com o qual conclui o capítulo de abertura de Raizes do Brasil e que está em plena sintonia com o Nietzsche e seus desdobramentos que vimos presentes no capítulo final:

Hoje a obediência como princípio de disciplina parece uma forma caduca e impraticável, e daí sobretudo a instabilidade constante de nossa vida social. Desaparecida a possibilidade desse freio, é em vão que temos descurado importar dos sistemas de outros povos modernos, ou criar por conta própria, um substitutivo adequado, capaz de superar os efeitos de nosso natural inquieto e desordenado. A experiência e a tradição ensinam que toda a cultura só absorve, assimila e elabora verdadeiramente os traços de outras culturas, quando estes encontram uma possibilidade de ajuste aos seus quadros de vida (Idem, p. 15). ${ }^{15}$

No curso do argumento apresentado no capítulo inicial de Raizes do Brasil, o que pode se ajustar àqueles quadros de vida é uma sociedade que somente pode existir e ser garantida por meio da força e do temor (cf. Idem, p. 5). Mais ainda, Sérgio Buarque assinala a conformidade das naçōes ibéricas com as formas de organização política que garantem a convivência humana, e assim as formas coletivas de vida, por meio da força, mormente as ditaduras militares (cf. Idem, pp. 11-12).

Portanto, desde o início da argumentação do livro encontramos formulado aquela desconfiança que reaparece ao final do livro e que condensa o meu argumento. Um tal diagnóstico é tanto mais significativo, quanto mais intimamente enlaça a teoria política latente com a filosofia da vida (à qual voltarei mais adiante). E, além disso, estabelece uma articulação orgânica e capital entre a argumentação que abre e aqueles capítulos que fecham o livro, ou seja, esta passagem do final do capítulo inicial é em alguma medida uma resposta- problematização às questões formuladas ao final do capítulo conclusivo de Raizes do Brasil ("Nossa revolução"). Temos aqui, no capítulo de abertura, uma indicação importante para o curso da "nossa revolução"; o parágrafo final do primeiro capítulo é, portanto, um possível pendant do parágrafo final do livro (ao qual chegaremos mais à frente).

Entre os capítulos de abertura e conclusão, Sérgio Buarque elabora consequentemente uma série de variações sobre o problema, guarnecendo-o dos passos argumentativos da exposição, de sorte que, ao concluir, de fato elabora uma síntese da argumentação e da exposiçãao, síntese essa que, como disse, se volta para a passagem citada do final do primeiro capítulo.

Vale a pena, ainda com vistas ao reforço, clarificação e prova do argumento, indicar alguns movimentos estratégicos do raciocínio desenvolvido ao longo de Raizes do Brasil (donde a importância das citações textuais). Se no capítulo sobre "Nossa revolução" alega-se a inadequação de fórmulas prontas para a evolução nacional, já no segundo capítulo ("Trabalho e aventura") Sérgio afirmara o seguinte, com relação ao período colonial:

Assim, o peculiar da vida brasileira por essa época parece ter sido uma acentuação singularmente enérgica do afetivo, do passional, do irracional, e uma estagnação, ou antes um afrouxamento correspondente das qualidades ordenadoras, discriminadoras, racionalizadoras. Quer dizer, exatamente o contrário do que 
poderia convir a uma população em vias de se organizar politicamente, de acordo com os conceitos modernos (Idem, pp. 32-33 - exemplo do cap. 2)

Transparece aqui novamente a desconfiança em face dos modelos impostos de fora, estranhos ao sentimento do povo. Será que essa peculiaridade mantém-se para além daquele período? Será que uma organização política moderna continuará sendo-nos estranha? Esse mesmo argumento é reforçado no capítulo terceiro ("O passado agrário"), quando afirma, com respeito ao decênio de 1850:

Apenas não se pode dizer que o país estivesse amadurecido para grandes empreendimentos de ordem econômica que lhe alterassem profundamente a fisionomia. Eles não encontrariam facilmente, em nosso temperamento e em nossos costumes, um ambiente adequado, não obstante toda a boa vontade de certas elites (Idem, p. 46 - exemplo do cap. 3).

Isso porque nosso temperamento e nossos costumes são derivados da "alma do povo" ou da "alma nacional"; ademais, note-se a visão favorável da elite imperial, uma modalidade da simpatia de Sergio Buarque pela oligarquia. Observe-se também que agora já passamos da época colonial para o Brasil independente, e as coisas continuam como antes.

No quarto capítulo ("O passado agrário [continuação]"), o problema assume a seguinte modulação:

Representando - como já notamos - o único setor onde o princípio de autoridade é indisputado, a família colonial fornecia a ideia mais normal do poder, da respeitabilidade, da obediência e da submissão. Resultava dessa circunstância um predomínio quase exclusivo, em todo o mecanismo social, dos sentimentos próprios à comunidade doméstica, naturalmente particularista e antipolítica, uma invasão do público pelo privado, do Estado pela Família. Explicam-se largamente, com isso, a nossa adaptação difícil ao princípio do Estado democrático [...] (Idem, p. 89 - exemplo do cap. 4).
Ou seja, uma outra forma de formular aquela disjunção, que mencionei, entre estrutura da personalidade e estrutura social. Digna de nota é a referência ao problema da adaptação/inadaptação, um tema recorrente no diagnóstico de extração conservadora (sendo a "crise de adaptação" uma de suas fórmulas prediletas). No quinto capítulo ("O homem cordial"), desdobra-se o argumento no seguinte passo:

Com efeito, onde quer que prospere e assente em bases muito sólidas a ideia de família - e principalmente onde predomina a família de tipo patriarcal - tende a ser precária e a lutar contra fortes restrições a formação e a evolução da sociedade segundo os conceitos modernos. A crise de adaptação dos indivíduos ao mecanismo social é, assim, especialmente sensível nos tempos atuais, com o decisivo triunfo de certas virtudes antifamiliares por excelência, como o são, sem dúvida, aquelas que repousam no espírito de iniciativa pessoal e na concorrência entre os cidadãos (Idem, pp. 97-98 - exemplo do cap. 5).

Por outras palavras, a família é hostil ao liberalismo e, dado que a família é uma forma que molda nosso modo de ser, somos refratários ao liberalismo. Há um agudo atrito, que resulta em crise de adaptação, causado pela penetração do ideário e da prática liberal em um contexto adverso: a imposição de algo que não nos é próprio e não coaduna com o "caráter nacional", com os "quadros de vida", com o "dever do povo".

Conjugam-se aqui dois momentos importantes do argumento de Raizes do Brasil. O primeiro é a oposição e a incompatibilidade de Estado e família. "Só pela superação da ordem doméstica e familiar é que nasce o Estado e é que o simples indivíduo se faz cidadão", diz Sérgio (Idem, p. 93). Entretanto, a família, entre nós, não é superada, de modo que o Estado não nasce saudável e íntegro, sendo antes algo como uma anomalia: ${ }^{16}$ daí a funcionalidade adquirida pelo argumento do patrimonialismo, colhido em Weber (cf. Idem, pp. 100, 101).

O domínio da família, tão concreta e corpórea, como diz Sérgio Buarque, deita raízes profundas 
em nossa sociedade, que parece não haver como extirpar em favor do Estado, tão abstrato e impessoal (os qualificativos em Idem, pp. 93, 94). Trata-se de uma forma que se estende por entre o passado, o presente e o futuro:

[...] é possível acompanhar, ao longe de nossa história, o predomínio constante das vontades particulares, que encontram seu ambiente próprio em círculos fechados e pouco acessíveis a uma ordenação impessoal. Dentre esses círculos, foi sem dúvida o da família aquele que se exprimiu com mais força e desenvoltura em nossa sociedade. E um dos efeitos decisivos da supremacia incontestável, absorvente, do núcleo familiar [...] está em que as relações que se criam na vida doméstica sempre forneceram o modelo obrigatório de qualquer composição social entre nós. Isso ocorre mesmo onde as instituiçōes democráticas, fundadas em princípios neutros e abstratos, pretendam assentar a sociedade em normas antiparticularistas (Idem, pp. 100-101, grifos meus).

Os termos grifados enfatizam o processo histórico que se projeta irredutível no presente e no futuro - uma das formas da ideia conservadora de "tradição", que perpassa o livro como um ostinato e que já encontramos em citação anterior. As mencionadas instituições democráticas devem ser aquelas instituídas pelo regime republicano, e com isso está selado o destino que Sérgio Buarque lhe atribui. Nesse aspecto, podemos notar certo parentesco com os críticos da República que pontearam naquela quadra histórica. ${ }^{17}$ Também fica patente o enquadramento da afirmação acerca do mal-entendido da democracia, em terra em que reinam as vontades particulares. Considerando que o autor provavelmente escreve em 1934-1935 (o livro foi impresso em outubro de 1936), a perspectiva delineada incorpora também praticamente todo o período que vai da Revolução ao Estado Novo, embora faltem as referências mais explícitas a isso. De todo modo, não é de descartar a ideia de que possamos ler o passo acima, e outros mais, como uma crítica ao regime de Vargas, assim como ao que lhe antecede. ${ }^{18}$
O segundo momento de importância é a crise. Sua discussão orienta as páginas iniciais do capítulo sobre o homem cordial e manifesta o diagnóstico do autor de Raizes do Brasil (nesse sentido, com "crise" Sérgio Buarque mobiliza uma noção central da crítica às patologias da modernidade). A passagem mais acima formula o problema da "crise de adaptação" e um dos trechos de que partimos falava em "inadaptação". Trata-se de uma noção central na exposição e fundamentação do argumento político do livro. "Crise de adaptação" e "inadaptação" são modos de compreensão do tempo histórico em processo, com vistas ao embate entre vetores político-sociais divergentes (que se concretizam nas dimensões psico e sociogenéticas). Como, nesse aspecto, o argumento de Sérgio Buarque privilegia precisamente o embate dos vetores, o problema da crise ganha centralidade analítica. Mesmo assim, não deixa de surpreender o modo como o autor, nessa altura da argumentação, procurou conduzir sua exposição: buscando aproximar o processo brasileiro do processo europeu da passagem do regime corporativo medieval para o "moderno sistema industrial" (cf. Idem, pp. 94-96). Se na Europa a dissolução das corporações e do trabalho artesanal implicou uma enorme crise, ela dá somente uma "ideia pálida" daquela que se desdobra sob nossos olhos, a crise de adaptação a um regime impessoal em uma sociedade assentada na família. Com efeito, se entre a família e o Estado há e somente pode haver descontinuidade e oposição, uma tal crise é um abismo intransponível, que ademais, à diferença da crise europeia, não possui um sujeito histórico capaz, de algum modo, de conduzir à sua superação - e aqui abre-se o flanco para uma elite oligárquica e/ou um ditador ("elites de governantes em torno de personalidades prestigiosas", como vimos), que conduza a nação para além da crise.

Além disso, o problema da crise explicita a discussão do processo sociogenético: "Em todas as culturas, o processo pelo qual a lei geral suplanta a lei particular, faz-se acompanhar de crises mais ou menos graves e prolongadas, que podem afetar profundamente a estrutura das sociedades" (Idem, p. 94) Essa formulação pode ser tomada como um mote para Raizes do Brasil, com a especificidade 
assinalada: que a lei particular não abdica de seus direitos, pois está profundamente entranhada na estrutura psicogenética. Vemos assim como o nexo de psicogênese e sociogênese, que formulei ao início, estrutura o livro.

Enfim, no sexto capítulo - "Novos tempos", do qual partimos - encontramos novamente uma variação cumulativa dos desenvolvimentos anteriores, quando Sérgio afirma que "na verdade a ideologia impessoal e antinatural do liberalismo democrático, com suas maiúsculas impressionantes e com suas fórmulas abstratas, jamais se naturalizou entre nós" (Idem, p. 122). Desse raciocínio, o autor extraiu a célebre conclusão de que partimos e que deve, na medida em que resulta de um processo cumulativo de argumentação, ser tomada ao pé da letra: "a democracia no Brasil foi sempre um lamentável mal-entendido" (Idem, p. 122). Continuaria sendo? A julgar pela argumentação apresentada em 1936, parece que sim.

$\mathrm{Na}$ verdade, Sérgio Buarque defende um princípio político simpático - no sentido de congruente - à alma do povo e à vida nacional, e não uma ideia estranha à ambos. No parágrafo final de "Novos tempos", Sérgio já anuncia, em chave cifrada, a epígrafe tomada a Nietzsche que encimará o capítulo seguinte, "Nossa revolução", ao destacar que a república foi implantada no Brasil por meio de um princípio negador - e não afirmativo. Tratava-se mais de negar o que o Brasil era, do que afirmar aquilo que ele é. Os mentores da república eram movidos pela "ideia de que o país não pode crescer pelas suas próprias forças naturais; deve formar-se de fora para dentro, deve merecer a aprovação dos outros (Idem, p. 131). ${ }^{19}$ Exatamente o oposto do que prega o Nietzsche da epígrafe e exatamente o que ele condena: a confusão do dever particular com o dever geral. Nesse sentido, essa página é literalmente um prelúdio à epígrafe e ao capítulo final do livro.

Essa linha de raciocínio é ainda acompanhada pelo argumento da maturação (maturação, tradição, organismo formam sistema no âmbito do pensamento conservador): nossa "evolução política” precisa pautar-se pelo amadurecimento das próprias forças da nação, jamais por uma imposição. As transformações políticas que vivenciamos - $\mathrm{a}$ in- dependência, as "conquistas liberais", a república "não emanavam de uma predisposição espiritual e emotiva particular, de uma concepção de vida bem definida e específica, que tivesse chegado à plena maturidade" (Idem, p. 123). Antes o contrário: impostas de cima para baixo, precipitadas, nada tem a ver com as "forças naturais" e com seu ritmo próprio de evolução. São formas exógenas e estranhas, condenadas a serem mal-entendidos, quando não levam nossa "vida verdadeira" a morrer de asfixia (Idem, p. 126). Sérgio Buarque sintetizou essa sua visão em uma analogia:

Como Plotino de Alexandria, que sentia vergonha do próprio corpo, acabaríamos por esquecer tudo quanto fizesse pensar em nossa própria riqueza emocional, a única força criadora que ainda nos restava, para nos submetermos à palavra escrita, à retórica, à gramática, ao $\mathrm{Di}$ reito abstrato (Idem, p. 126).

Todo o argumento de Raízes do Brasil reside, em última instância, em detectar nossa força criadora, impugnar suas contrafaçôes e negaçôes e pugnar por sua realização. A pergunta que se apresenta, então é: qual a forma política madura que nossa força criadora pode assumir?

Como procurava sugerir, Sérgio Buarque apresenta um descompasso entre uma estrutura da personalidade hostil ao liberalismo, à igualdade e ao bem comum, e um processo social que tenta incrementar tais princípios. Isto é, a modernização nacional não encontra "ambiente adequado" (a expressão é dele, em passo citado mais acima) e permanece truncada, travada mesmo. ${ }^{20}$

Subjacente a esta ideia da necessidade de uma correspondência feliz entre estrutura da personalidade e estrutura da sociedade está uma concepção de unidade, cujo sujeito é o "povo" (no sentido já apontado anteriormente). Também aqui resvalamos em um argumento nietzscheano - a unidade de todas as manifestações de um povo, seu "estilo", como sua verdade, e a crítica às sínteses falsas e forçadas (cf. Nietzsche, 1988 [1873-1876], pp. 274, 326, 333).

Trocando em miúdos, podemos dizer que todas as soluçôes que não forem afins à estrutura 
da personalidade permanecerão mal-entendidos, como é o caso da democracia. A solução sugerida em Raízes do Brasil é a procura de uma estrutura da sociedade afim ao personalismo, ao mesmo tempo em que uma transformação lenta e gradual dessa mesma estrutura da personalidade. Não há revolução que não seja, ao menos entre nós, lenta e gradual: ela implica o movimento conjunto que articula a transformação da estrutura de personalidade - uma transformação que se faz somente no longo curso das gerações - à transformação da estrutura da sociedade - que se pode imaginar fazer em curto prazo, mas que depende, para sua concretização real, da estrutura da personalidade correspondente. Daí o amadurecimento, o tempo necessário para a transformação e a adaptação, para a criação do "ambiente adequado"; a importância da tradição, como balizadora da transformação e articuladora de passado, presente e futuro (os mortos, os vivos e os vindouros, como formulava Burke); e o organismo, seja como modelo vital, seja como lógica organizacional (donde a impossibilidade dos transplantes institucionais) - nesse sentido, leia-se, uma vez mais, o final do capítulo inicial do livro, citado anteriormente ("A experiência e a tradição ensinam...").

O lento processo de transformação e desenvolvimento é então o tema do início do capítulo final de Raízes. A "grande revolução brasileira” foi um processo que perpassou o século XIX e que se revela na transição do "mundo rural" para o "mundo das cidades", uma "transformação social de grandes proporções” (Hollanda, 1936, pp. 137, 140). Mas como no Brasil "iberismo e agrarismo confundem-se”, essa transição significa também o "aniquilamento das raízes ibéricas de nossa cultura” (Idem, p. 137). Entretanto, esse aniquilamento não se consumou ainda, e não é claro como se resolverá. O "novo sistema”, o "estilo novo", o "advento de um novo estado de coisas", embora "inevitável” (cf. Idem, pp. 136, 137), não apresenta seus contornos definidos, exceto no que diz respeito ao movimento mais amplo de predomínio das cidades, ou seja, de deslocamento do centro cultural, político, econômico e social para a cidade. Podemos compreender esse contorno no âmbito da transformação na estrutura da sociedade, para a qual a correspondente transformação na estrutura da personalidade permanece indefinida e até mesmo faltante: "O americano ainda é interiormente inexistente", diz ele (Idem, p. 137). Este é o nó do problema: a disjunção, na qual um domínio se transforma em ritmo diferente do outro, criando um descompasso prenhe de consequências.

Uma de suas feições é que a "forma de nossa cultura permanece nitidamente ibérica e lusitana”, no mesmo momento em que se afirma o aniquilamento progressivo de nossas raízes ibéricas.

Essa contradição é formulada em termos de "forma": perdemos uma forma própria, sem conquistar propriamente uma nova. Ausência de forma é sinônimo, por outro lado, de falta de ordem, anarquia, aqueles termos que já tivemos oportunidade de comentar. É nessa altura do argumento que se insere aquele passo, citado anteriormente, acerca dos velhos senhores rurais do tempo do Império, que garantiam a solidez das instituições nacionais. Não exatamente por mérito próprio, mas em virtude da estrutura social que embasava o regime monárquico: o mundo rural.

A urbanização contínua, progressiva, avassaladora, fenômeno social de que as instituições republicanas deviam representar a forma exterior complementar, destruiu esse poderoso esteio rural, que fazia a força do regime decaído, sem lograr substituí-lo por nada de novo (Idem, p. 141, grifo meu).

Vê-se o malogro da República, que resulta em situação "trágica": falta uma forma política que dê corpo à nação. Restos monárquicos, sem uma estrutura que lhes corresponda, e uma nova estrutura, sem uma forma que lhe corresponda.

"Forma" é o vocábulo que Sérgio Buarque privilegia para designar a condensação e a cristalização do estrato profundo da vida do povo e da nação ("instinto", "forças naturais" etc.). Assim, forma e estrutura são maneiras de aproximar-se do nexo de psico e sociogênese. O parágrafo final de Raízes do Brasil, para alguns enigmático e cifrado, está construído sobre a noção de forma e da contraposição de vida e espírito. Ambos os motivos foram desdobrando-se continuamente ao longo da narrativa, 
ordenando subterraneamente o argumento e aflorando por vezes à superfície.

Podemos aproximar a ideia de forma do que vimos formulado anteriormente por Nietzsche como "dever". Assim como o dever desdobra-se em verdadeiro e concreto, de um lado, e abstrato, de outro, pode ocorrer também com a forma. Sérgio Buarque, na trilha do filólogo alemão, toma o partido decidido pelo "dever do povo": seu estrato mais profundo, e portanto mais verdadeiro (toda uma terminologia que configura um "jargão da autenticidade", para retermos uma fórmula consagrada). Podemos, com isso em mente, ler uma vez mais aquele parágrafo culminante do livro, que nada mais faz do que destilar tudo o que temos visto:

O essencial de todas as manifestações, das criações originais como das coisas fabricadas, é a forma. A realização completa de uma sociedade também depende de sua forma. Se no terreno político e social o liberalismo revelou-se entre nós antes um destruidor de formas preexistentes do que um criador de novas; se foi sobretudo uma inútil e onerosa superfetação, não será pela experiência de outras elaboraçōes engenhosas que nos encontraremos um dia com a nossa realidade. Poderemos ensaiar a organização de nossa desordem segundo esquemas sábios e de virtude provada, mas há de restar um mundo de essências mais íntimas que, esse, permanecerá sempre intacto, irredutível e desdenhoso das invençôes humanas. Querer ignorar esse mundo será renunciar ao nosso próprio ritmo espontâneo, à lei do fluxo e do refluxo, por um compasso mecânico e uma harmonia falsa. Já temos visto que o Estado, criatura espiritual, opõe-se à ordem natural e a transcende. Mas também é verdade que essa oposição deve resolver-se em um contraponto para que o quadro social seja coerente consigo. Há uma única economia possível e superior aos nossos cálculos e imaginações para compor um todo perfeito de partes tão antagônicas. $\mathrm{O}$ espírito não é uma força normativa, salvo onde pode servir à vida social e onde lhe corresponde. As formas exteriores da sociedade devem ser como um contorno congênito a ela e dela inseparável: emergem continuamente das suas necessidades específicas e jamais das escolhas caprichosas. Há, porém, um demônio pérfido e pretensioso, que se ocupa em obscurecer aos nossos olhos estas verdades singelas. Inspirados por ele, os homens se veem diversos do que são e criam novas preferências e repugnâncias. É raro que sejam boas (Idem, pp. 160-161).

Notem como alguns daqueles tópicos recorrentes do pensamento conservador, que assinalei no início, comentando uma outra passagem, reaparecem aqui, novamente formulados com clareza e decisão, assim como outros, que venho assinalando no curso deste artigo: o desencontro com a realidade; a essência supra-histórica; o mecânico versus o orgânico; a maturação; interior e exterior etc. A eles se ajunta um outro motivo característico do pensamento conservador dos anos de 1920-1930: a contraposição de vida e espírito. Busca-se um equilíbrio, um andamento conjunto e articulado, em que um não se faça às custas do outro; fundamental é que o espírito (o Estado) não triunfe sobre a vida - antes o contrário: seguindo a lição de Nietzsche, é a vida que deve moldar o espírito, é este que deve estar à serviço da vida. E esse contraponto só pode ser de um modo, e este modo está além do cálculo e da fantasia humanos: só pode ser obra, então, de um poder superior, extramundano, supraterreno, em uma palavra: de um Deus. Não sem razão o autor fala de um "todo perfeito de partes antagônicas”, uma síntese única que só o poder supremo e absoluto seria capaz de realizar. Não é fortuito, portanto, que apareça, nesse exato momento, nessa encruzilhada, à meia-noite, a figura do demônio, como o poder que seduz e conduz para o caminho errado.

O essencialismo, recorrente, acaba amiúde em uma absolutização de noções como "povo", "cultura", "nação", e é nesse sentido que Sérgio Buarque se aproxima de modo mais ousado de autores como Klages (cf. Horkheimer, 1990 [1926], p. 332; voltarei à questão). Ademais, o linguajar ao primeiro olhar metafórico precisa ser ponderado com precisão, pois talvez não se trate de linguagem figurada. A crítica recorrente ao racionalismo, sobretudo ao final do livro, desvela o irracionalismo ao qual tende o autor. 
A possibilidade de afinação do homem cordial com os princípios liberal-democráticos não é descartada, mas essa afinação é, quando muito, de superfície: não se converte em forma (cf. Hollanda, 1936, pp. 154-156). Aliás, caso se convertesse, seria decerto, para Sérgio, a grande contribuição brasileira à civilização universal.

O mal-entendido da democracia, assim, formula o problema da especificidade nacional e da inadequação das soluções exógenas e estranhas à "alma do povo". Daí o anseio de Sérgio Buarque de Holanda por aquela "superação da doutrina democrática” (Idem, pp. 149-150), que nos é imprópria, pugnando por uma forma que nos seja "espontânea" e não "estranha ao temperamento nacional" (Idem, pp. 151, 154). Portanto, que respeite aquela noção verdadeiramente positiva e nossa que é o personalismo e suas formas políticas, a oligarquia e a formação de elites.

Apesar disso, não está descartada a possibilidade de uma transformação de longa duração na estrutura da personalidade, quem sabe uma superação do personalismo e a abertura para a possibilidade de uma sociedade na qual a democracia deixe de ser um mal-entendido. De todo modo, estamos falando de uma longa e "nossa revolução", de lenta maturação, que se faz - ou fará - somente no curso vagaroso das geraçôes (é isso, justamente, que explica o "nossa" em "nossa revolução"). No entremeio, entre o tempo presente e esse futuro longín- quo, aberto e indefinido cabe às elites, e mesmo ao ditador, buscar impor, pela força, por sua vontade, um mínimo de acomodação modernizante. É precisamente por essa razão que estamos condenados a viver uma "crise de adaptação", que a curto prazo não se deixa simplesmente resolver.

\section{Adendos à argumentação precedente}

Creio que muito da dificuldade em reconhecer esse andamento e posicionamento de Sérgio Buarque em Raizes do Brasil deve-se, como disse, à vicissitudes da recepção do livro, e uma das principais, senão mesmo a principal, são as alterações textuais, realizadas sobretudo para a segunda edição do livro, de 1948. Sua consideração sugere que Sérgio Buarque, entre uma edição e outra, redefiniu sua posição e seus valores políticos. Gostaria de argumentar que as alterações textuais, embora complexas, têm primordialmente o sentido de sombrear os tópicos de diagnóstico e fundamentação política tratados anteriormente. ${ }^{21}$ Nessa direção, podemos avançar retomando simplesmente um trecho de que partimos e confrontando-o com sua versão de 1948:

Não é preciso comentar o quanto o texto de 1948 atenua o de 1936; ou formulando de outra maneira, o enorme incômodo que o texto de 1936 traria ao autor, se republicado tal e qual em 1948 (ou seja, como já aludi, em pleno momento de "rede-

\section{6 (1 ed., p. 152)}

"Entre nós, já o dissemos, o personalismo é uma noção positiva - talvez a única verdadeiramente positiva que conhecemos. Ao seu lado todos os lemas da democracia liberal são conceitos puramente decorativos, sem raízes profundas na realidade. Isso explica bem como nos países latino-americanos, onde o personalismo - ou mesmo a oligarquia, que é o prolongamento do personalismo no espaço e no tempo - conseguiu abolir as resistências da demagogia liberal, acordando os instintos e os sentimentos mais vivos do povo, tenha assegurado, com isso, uma estabilidade política que de outro modo não teria sido possível. A formação de elites de governantes em torno de personalidades prestigiosas tem sido, ao menos por enquanto, o princípio político mais fecundo em nossa América”.
1948 (2 ed., pp. 275-276); 2006 (p. 202)

"É inegável que em nossa vida política o personalismo pode ser em muitos casos uma força positiva e que ao seu lado os lemas da democracia liberal parecem conceitos puramente ornamentais ou declamatórios, sem raízes fundas na realidade./Isso explica como, entre nós e, em geral, nos países latino-americanos, onde quer que o personalismo - ou a oligarquia, que é o prolongamento do personalismo no espaço e no tempo - conseguiu abolir as resistências liberais, assegurou-se, por essa forma, uma estabilidade política aparente, mas que de outro modo não seria possível”. 
mocratização" 22 ). Não vou avançar mais na exemplificação e comentário, que nos levariam, por sua extensão, a outro artigo. A simples leitura do passo e a ponderação das alterações já permitem ao leitor concluir por si mesmo.

Entretanto, vale a pena chamar a atenção para uma outra modalidade das alterações textuais realizadas para a edição de 1948: os ocultamentos e os expurgos. Julgo que são muito sintomáticos e gostaria de destacar alguns. Comecemos por Nietzsche, cuja importância capital já pude realçar.

Em 1936, o capítulo final, "Nossa revolução", trazia a epígrafe de Nietzsche emoldurando e circunscrevendo a problematização geral e oferecendo a perspectiva geral de discussão. Mais tarde, nesse mesmo capítulo, Nietzsche é novamente referido (na discussão que também mencionei anteriormente) para oferecer um fundamento central para o argumento de Sérgio. Ora, na segunda edição, "revista e ampliada", como consta na capa, Sérgio eliminou Nietzsche da abertura do capítulo final e daquela fundamentação mencionada. Ou seja: aquele enquadramento do argumento, baseado em Nietzsche, é expurgado. Se algo entra em seu lugar, ou se resta um vazio, é questão que exigiria a discussão da segunda versão do livro, publicada em 1948. Fico apenas na constatação do expurgo; e inquiro qual o seu sentido: trata-se precisamente de eliminar um elemento que permitiria situar Raizes do Brasil, e seu autor, em um campo político conservador. ${ }^{23}$ Expurga-se (mas jamais integralmente) um fundamento vitalista e irracionalista (ou anti-intelectualista) do pensamento de Sérgio em Raizes do Brasil (não interessa, para nossa discussão, avançar no debate em torno da possibilidade de Nietzsche poder adequadamente ser assim rotulado e compreendido, pois o que importa é que, no contexto da leitura e utilização de Nietzsche por Sérgio, esses vetores orientavam a recepção da obra).

Os leitores de Sérgio Buarque sabem que esse expurgo é tematizado retrospectivamente em Tentativas de mitologia, um bom exemplo de construção biográfica ou ilusão autobiográfica (ademais, plenamente legítimo). $\mathrm{Na}$ edição atual de Raizes, restou apenas uma referência a Nietzsche, de menor importância no plano da argumentação geral (cf. Hollanda, 1936, p. 103; Holanda, 2006, p. 161).
Um outro expurgo interessante e sintomático é Oswald Spengler. Trata-se de caso similar ao anterior, embora de relevância incomparavelmente menor. Spengler é citado na edição de 1936 e desaparece na de 1948. Como se trata de mais um autor situado indiscutivelmente no campo irracionalista e conservador, esse expurgo forma sistema com o anterior.

Pode-se argumentar, e com razão, que o argumento de Sérgio independe de Spengler. Este é citado para justificar asserçôes muito pontuais (cf. Hollanda, 1936, pp. 106, 165). Importa mais é a revelação e a explicitação da leitura e utilização de Spengler por Sérgio. Mas o mais importante é o fato de que ele é retirado do texto; ou seja, é o próprio movimento de expurgo que é revelador.

A frequentação de Sérgio Buarque de autores do campo conservador e antidemocrático encontra outra figura de destaque no "ilustre professor de Direito Público da Universidade de Bonn”, Carl Schmitt (Idem, p. 155). Embora a menção a Schmitt seja pontual, ela ganha relevância ao lembramos que, em 1935, Sérgio publicara "O Estado totalitário”, uma resenha de $O$ conceito do politico, o mesmo livro referido em Raizes do Brasil (cf. Idem, 1988 [1935b]). Trata-se portanto de uma resenha que Sérgio escreveu enquanto dava redação final ao seu livro e na qual glosa Schmitt em perspectiva favorável. É um exemplo interessante para sugerir como Sérgio Buarque sentia-se próximo de formulaçōes como as de Schmitt, e que foram, sobretudo por conta das reelaborações e das alterações do texto, obscurecidas e desvigoradas, em favor de um pretenso comprometimento democrático. Mas basta ler a resenha de Sérgio para ver que a questão da democracia sequer é mencionada: ela simplesmente não é um tópico de discussão - enquanto em Raízes ela é um tópico de discussão, ou seja, um mal-entendido a ser esclarecido.

Nesse contexto, valeria a pena indagar se o Estado forte, mesmo imposto, não seria, no entender de Sérgio Buarque, uma resposta compatível com a situação brasileira, justamente porque ela se caracteriza por uma situação na qual o Estado impessoal não se concretiza, tolhido pelo poder privado. Não vimos Sérgio afirmar a disjunção de família e Estado e juntar a isso uma caracterização 
da formação nacional como lastreada nesse mesmo círculo familiar? (cf. Idem, 1936, pp. 88-89, 93, 113 passim) Ou seja: o Estado nos é estranho, mas por outro lado indispensável como instância organizatória da vida nacional. Como implementá-lo? Se Sérgio Buarque, como destaquei, não descarta a tirania, talvez visse ele no ditador a figura hodierna do tirano. E talvez fosse mesmo somente uma daquelas "personalidades prestigiosas" quem pudesse, no entender de Sérgio, garantir um Estado com a "solidez orgânica" necessária, aquela unidade viva, irracional e nascida da vida do povo. Lembremos ainda que o Estado é espírito impondo-se sobre a vida. A solução de Sérgio busca na "vida nacional" o fundamento do Estado; e como o personalismo é a nossa noção positiva por excelência, caberia realizar um Estado sobre ele assentado, portanto um Estado antiliberal. Quais são as alternativas postas na mesa, naquela situação histórica, para essa questão? ${ }^{24}$

Ademais, embora Schmitt seja citado nominalmente apenas uma vez em 1936, há pelo menos duas outras passagens do texto que reverberam formulações suas: uma delas já foi inclusive citada: trata-se da passagem, no capítulo de abertura de Raizes do Brasil, na qual Sérgio menciona a obediência como "o único princípio político verdadeiramente forte" dos povos ibéricos - princípio esse que ganha forma na ditadura, diz ele. Foram então os jesuítas aqueles capazes de levar mais longe o "princípio da disciplina pela obediência" - no que transparece a admiração de Sérgio pelos feitos dos jesuítas, verdadeiro "prodígio de racionalização" (Idem, pp. 14-15). Posteriormente, na célebre discussão acerca da oposição de família e Estado (na abertura do capítulo sobre o "homem cordial"), encontramos novamente ecos da doutrina schmittiana na absolutização do Estado (cf. Idem, pp. 93ss).

O caso Schmitt oferece mais um expurgo de interesse, pois a partir da segunda edição ele desaparece do capítulo final de Raízes do Brasil - um capítulo central, no que diz respeito à concepção política do autor - para comparecer, de modo totalmente acessório, como apêndice em uma nota do capítulo sobre o homem cordial. Nessa reelaboração, Schmitt não surge mais como um teórico político que Sérgio respeita e do qual se aproxima, mas apenas como uma comprovação inócua de uma assertiva (cf. Idem, 2006, p. 219).

Por fim, há ainda um procedimento argumentativo e analítico em Raizes do Brasil que pode ser aproximado de Carl Schmitt: o pensamento por oposiçôes, ou melhor, por extremos. Usualmente, a recepção de Raizes do Brasil, ao perceber isso, procurou atribuir-lhe caráter dialético ou, na expressão de Antonio Candido, que fez escola, falar em "senso dos contrários" (aliás, não se pode esquecer, nem subestimar, os nexos do pensamento conservador com a dialética, a começar por Hegel). Contudo, tendo a crer que encontramos aí, antes de mais nada, uma afinidade schmittiana, ou melhor, um fenômeno característico do pensamento conservador: pensar por polaridades (cf. Mannheim, 1984 [1925], pp. 172, 178).

Um último exemplo foge ao corpo textual de Raízes do Brasil, mas é indicativo do movimento de obscurecimento das afinidades antidemocráticas e irracionalistas de Sérgio Buarque de Holanda nos anos de composição de Raizes do Brasil. Trata-se de Ludwig Klages, cuja influência em Sérgio, a julgar pelos comentários de Manuel Bandeira, foi ampla e profunda. No texto que publicou por ocasião do retorno de Sérgio da Alemanha, Bandeira pinta um Sérgio Buarque discípulo de Klages, quase um apóstolo (Bandeira, 1988 [1931], pp. 292-293). Também a correspondência com Raul Bopp sugere o impacto da leitura de Klages. ${ }^{25} \mathrm{O}$ interesse, no caso de Klages, difere dos casos anteriores: é que ele foi tomado pelo próprio Sérgio, sua empreita autobiográfica, como testemunho de seu abandono dos elementos irracionalistas que o influenciaram naqueles tempos. Por outras palavras, reconhecendo a influência de Klages e afirmando que fora um encanto momentâneo e sem maiores consequências para a formação de seu pensamento, o próprio Sérgio constrói uma espécie de cordão sanitário em face do irracionalismo, indubitavelmente presente em Raizes do Brasil. Assim, em seu artigo sobre Bopp, ele comenta o encanto comum com Klages em chave irônica e distanciada (Holanda, 1978, pp. 127-128). O mesmo tom é retomado na apresentação de Tentativas de mitologia, de modo que vislumbramos um processo formativo no qual o autor, embora inicialmente seduzido pelo mal cami- 
nho das "filosofias místicas e irracionalistas (Klages etc.), que iam pululando naqueles últimos anos da República de Weimar", foi capaz de se corrigir e remir (Holanda, 1979, p. 30; cf. Candido, 1982, pp. 124-125). ${ }^{26}$ Ou seja: Klages foi escolhido como uma espécie de nariz de cera, de modo que a renúncia a ele simbolizaria e testemunharia a renúncia aos autores irracionalistas e antidemocráticos como um todo. Com isso, não se menciona Schmitt, Spengler, Nietzsche, Keyserling, Breysig - todos ele presentes na edição de 1936 de Raizes do Brasile literal ou simbolicamente expurgados posteriormente. ${ }^{27}$

A forma mais imediata de tornar patente o irracionalismo e o vitalismo em Raizes do Brasil é a terminologia, que jamais é neutra. Também ela mereceria um artigo à parte, tamanha a riqueza de desdobramentos que se pode encontrar, seja na análise terminológica propriamente dita, seja nas alteraçôes terminológicas para a edição de $1948 .^{28}$ Mas, em vez de explorar nessa direção, gostaria de concluir com uma nota sobre o vitalismo, o irracionalismo (ou, se preferirem, o antirracionalismo) e a filosofia da vida, que pulsam tão fortemente no clássico de 1936.

O problema precisa ser pensado (ao menos inicialmente) no âmbito das discussões exemplares de Troeltsch e Mannheim, que não posso aqui, evidentemente, reconstruir (cf. Troeltsch, 1922; Mannheim, 1984 [1925]). Vou somente indicar alguns elementos que permitem situar o livro de 1936 na constelação irracionalista e conservadora (que nada tem de simples, nem é homogênea, comportando amplo espectro de variação) indicada por aqueles dois sociólogos. ${ }^{29}$ De modo geral, o vitalismo pode ser compreendido como uma resposta ao racionalismo moderno e, em especial, ao do século XVIII, dos enciclopedistas e da Grande Revolução. Sérgio elabora o nexo de racionalismo e Revolução Francesa de modo crítico, mas deixa de analisar criticamente os antecedentes e os fundamentos de sua própria posição: a reação ao racionalismo, a linhagem crítica e opositora a ele e à Revolução, na qual a vida se contrapõe ao conceito. Com efeito, é uma ênfase da vida, às custas do conceito, que encontramos em Raizes do Brasil. Critica-se o caráter abstrato de uma racionalização que tolhe progressivamente os elementos, as dimensões e a riqueza próprias da "vida", e em termos políticos do "povo" e da "nação". "Povo", "nação" e "realidade" são diminuídas pelo conceito racional.

Exatamente a este ponto se liga a célebre distinção crítica do legal-real e suas variações. Nas palavras de Mannheim, que perseguiu o problema já nos inícios do século XIX, contribuindo para demarcar esta linhagem de nosso pensamento político, "a forma mais primitiva de combate do modo de pensamento racionalista-dedutivo mediante um recurso à vida consiste em contrapor à 'constituição escrita' a realidade, que sempre é mais rica e mais viva do que a palavra escrita" (Mannheim, 1984 [1925], p. 168).

Em paralelo, delineia-se toda uma plêiade de motivos, que serão desdobrados ao longo do tempo pelos conservadorismos de variada lavra: alguns deles fundamentais, como a família versus o contrato, o sentimento versus o racional, a experiência interior versus a experiência mecânica (cf. Mannheim, 1984 [1925], p. 85; Nisbet, 1952) - todos estes presentes e mesmo estruturantes no pensamento de Sérgio Buarque em 1936. E a capacidade de operar de modo dinâmico com as noçôes, que para alguns permitiria situar Sérgio entre os pensadores progressistas, é também um elemento característico do conservadorismo, que o compartilha com o revolucionarismo progressivo (cf. Mannheim, 1984 [1925], pp. 184-185). Nisso se percebe, ademais, as afinidades existentes entre o pensamento conservador e o pensamento revolucionário de esquerda (cf. Idem, pp. 89-91).

Em Raizes do Brasil, toda a busca das origens ibéricas e toda a interpretação do processo nacional, que perfazem as raízes da nação, assim como todo o sintomático jargão dos instintos, das forças, dos sentimentos, das raízes, da espontaneidade revelam seu engaste na linhagem do pensamento conservador, como podemos aferir com exatidão e perspicácia em vários dos estudos que Mannheim publicou nos anos de 1920:

Para se obter um parâmetro de orientação, não se pode basear em vontades subjetivas, mas é preciso evocar as forças e ideias objetivadas em nós e no nosso passado, evocar o espírito que criou até agora, através de nós, as 
nossas obras. Mas essa ideia, esse espírito não é encontrado racionalmente, nem projetado como a melhor possibilidade existente, mas sim apreendido interiormente em nós como uma "força silenciosa atuante" (Savigny) ou nas criaçôes coletivas da comunidade concreta do povo, da nação, do Estado, como uma enteléquia que se desdobra, como uma forma interior [...]. A forma interna de uma individualidade histórica qualquer, seja ela a de uma personalidade singular, seja a de um espírito do povo, e as circunstâncias exteriores, em conjunto com o passado que está por detrás dela, determinam tendencialmente a configuração do devir. Justamente por isso uma configuração histórica qualquer não pode ser produzida, mas, como uma planta, cresce de um centro interior (Idem, pp. 216-218).

Eis aí, pintada com nitidez, a matriz que alimenta Sérgio Buarque; creio que a linha de argumentação de Raizes do Brasil singra essas águas e que todo leitor pode reconhecer, na descrição de Mannheim, o manancial que a alimenta. O mesmo Mannheim não deixa de citar uma matriz geradora, o Adam Müller de 1810, que poderia muito bem servir de mote, ao lado de Nietzsche, aos capítulos finais do livro de 1936:

As constituições dos Estados não se deixam inventar; o cálculo mais sábio é aqui tão impotente quanto a ignorância completa: para a índole [Gemüth] de um povo e a força e a ordem que dela emanam não há nenhum substitutivo, nem mesmo nas cabeças as mais inteligentes, nem nos maiores virtuoses (Müller apud Mannheim, 1929, p. 218).

Essas quatro linhas são quase uma súmula do capítulo final de Raízes do Brasil, se tivermos a paciência de as escandir e perscrutar minuciosamente. Somente a índole do povo pode oferecer uma solução verdadeira para a nossa revolução, assim como o Deus que mencionei anteriormente corresponde à enteléquia de que falava Mannheim. Mas tudo isso ainda não permite fechar a conta, pois resta precisar o problema do vitalismo, sem dúvida pre- sente na linhagem apresentada, mas ainda não tematizado com atenção. ${ }^{30}$

A ideia iluminista de que a razão é, a um só tempo, a finalidade da história e a sua força motriz foi remodelada, na Alemanha, no âmbito de uma certa filosofia, no espírito, que encarnaria aquela razão. Ao longo do século XIX, testemunhamos uma transformação desse espírito impregnado de (e realização mesma da) razão, em vida, de teor irracional (cf. Korff, 1923). Sobretudo os movimentos antirracionalistas, românticos e conservadores concretizaram a elevação da vida a fundamento da dinâmica histórica. No bojo dessa transformação, a pesquisa histórica converteu-se menos em filologia e crítica do que na procura de grandes nexos históricos, na definição das linhas fundamentais de um processo de desenvolvimento (cf. Troeltsch, 1922, pp. 493ss). E, para a compreensão desses nexos, a intuição passa a desempenhar o papel central, com o que ocorre um deslocamento de uma razão supra ou trans-individual para uma psicologia. Não é por outra razão que as "psicologias" passam a ganhar força na compreensão dos processos históricos, e é por isso que aquele artigo de Sérgio Buarque, que antecedeu a publicação de Raizes do Brasil, intitulava-se "Corpo e alma do Brasil: ensaio de psicologia social" (Holanda, 2006 [1935a]).

Nessa transformação, Nietzsche desempenhou, sem dúvida, um papel decisivo, e essa é uma das razōes de sua relevância para o Sérgio Buarque de então - que, ademais, confessava sem peias suas tendências irracionalistas (cf. Bandeira, 1988 [1931]). Nietzsche buscava iluminar aquelas camadas mais profundas, mais amorfas, da qual brota o processo de desenvolvimento histórico, e esse motivo é uma das inspirações do autor de Raízes do Brasil. Nessa modalidade de investigação, a intuição ganha um papel de destaque, como procedimento central de experimentação do mundo. Complementar a ela é a "visada" (Anschauung) no processo histórico: vida, irracionalismo, intuição e Anschauung formam sistema em contraposição a espírito, racionalismo, construção, conceito (cf. Mannheim, 1964 [1924], p. 273; Horkheimer, 1990 [1926], pp. 269ss), e demarcam as águas por onde navegava Sérgio Buarque.

Vida, que é fluxo e espontaneidade, e sua cristalização em formas (ou instituiçôes), que a sufo- 
cam, exaurem, ordenam: esse é o arcabouço expressivo de Raizes do Brasil, escrito utilizando essa terminologia e essa concepção geral. Que o fluxo vital marque forte presença na armação heurística do livro de 1936 e ocupe posição central na construção de uma de suas noções capitais, o homem cordial, não deve haver dúvida. Com efeito, como se argumenta em outro texto,

[...] a cordialidade consiste, quase paradoxalmente, em uma forma de sociabilidade cujo conteúdo em certa medida resiste a ser formalizado por completo, ou melhor, consiste em uma forma social cristalizada, mas de cuja composição faz parte certa margem de espontaneidade, de fluxos vitais que persistem e que não se deixam tolher completamente por seu investimento em formas constituídas (Goldfeder e Waizbort, 2009, pp. 34-35). ${ }^{31}$

Esse é um bom exemplo para se aquilatar como a filosofia da vida adentra nas camadas mais profundas do livro.

Mas não só. O propagado despertar do namoro com Klages não condiz com a reiterada utilização do motivo do espírito como negador da vida "der Geist als Widersacher der Seele" ["o espírito como oponente da alma”], para lembrar o título da obra máxima de Klages. É o que se pode aferir em algumas passagens de Raizes do Brasil, como por exemplo aquela, na discussão do homem cordial, na qual se afirma: "Por meio dessa estandardização das formas exteriores da cordialidade, que não precisam ser legítimas para se manifestarem, revela-se um dos mais decisivos triunfos do espírito sobre a vida" (Hollanda, 1936, p. 102).

Essa ideia do triunfo do espírito sobre a vida é central para uma vertente da filosofia da vida, de pendor irracionalista e conservador, com a qual Sérgio Buarque parece se alinhar, ao menos em muitos momentos. ${ }^{32}$ Já a tínhamos encontrado no parágrafo final do livro, citado mais acima.

Ademais, é sabido que o vitalismo estava bem presente no ambiente intelectual do jovem Sérgio Buarque, nos anos que antecederam sua ida à Alemanha - para tanto, basta ler seus artigos dessa época, assim como ter em mente a sua proximidade àquele "homem essencial", Graça Aranha (cf. Holanda, 1996 [1924]). ${ }^{33} \mathrm{Na}$ verdade, a penetração de um vitalismo, mais ou menos difuso, mais ou menos arquitetado teoricamente, mais ou menos transparente, é flagrante no contexto das primeiras décadas do século, ${ }^{34}$ cumprindo ainda o papel de reação, de extração romântica e conservadora, a processos de transformação e modernização social de variada lavra. ${ }^{35} \mathrm{Na}$ nossa "crise de adaptação", este foi também um elemento em jogo.

Por fim, é sabido que Sérgio frequentava Nietzsche desde muito antes de sua ida a Berlim; assim como se reconhece a penetração difusa da filosofia da vida e da filosofia da cultura de tirada vitalista no início do século. De resto, os autores citados e posteriormente expurgados por Sérgio revelam algumas das suas predileções e companhias naqueles anos. Por outro lado, as alterações mostram que, em algum momento entre 1936 e o início dos anos de 1940, Sérgio Buarque de Holanda reformulou seus valores e posicionamentos políticos, passando a assumir uma defesa da democracia que marcará sua biografia a partir de então. Tudo isso, evidentemente, não diminui em nada a força do livro de 1936, antes o contrário: talvez seja em virtude de suas ambiguidades intensas que o livro continue sendo, desde que foi publicado pela primeira vez, tão atual e provocador.

\section{Notas}

1 Para o contexto geral da discussão, ver Botelho (2009) e Brandão (2007).

2 Antonio Candido (2008 [1998]) retornou uma vez mais ao problema, relativizando-o ao afirmar que propõe "uma leitura relativamente livre".

3 Um caso exemplar é Vecchi (2008, p. 370), onde se lê: "A minha opinião [...] é que o elo que sutura todas as irregularidades de Raízes do Brasil, que combina formas tão ímpares, em uma palavra que dá densidade e unidade no multíplice do representado e da representação, é um atento investimento nas metáforas do discurso." Ressalto que não nego os valores cognitivo e expressivo da metáfora, mas julgo que eles precisam ser ponderados, ainda mais em se tratando de um texto de análise histórico-sociológica. Tudo isso decerto tem a ver com o que se costuma 
denominar "ensaísmo", mas foge ao meu tema; ver Waizbort (2000).

4 Manifesto tanto nos prefácios, como em entrevistas, como em outros textos seus.

5 Até onde acompanho a bibliografia a respeito, falta um estudo aprofundado da recepção contemporânea do livro, no momento de sua publicação em 1936. Um estudo de corte skinneriano faz falta e ajudaria muito a melhor qualificar o sentido das afirmações de Sérgio Buarque.

6 Publicado em 1936, portanto depois de 1930 e antes de 1937 - mas não vou avançar nessa direção, sem dúvida da maior importância, em virtude da economia da argumentação.

7 Nesse sentido, o modo como Sérgio Buarque utiliza essa noção, central em Raízes do Brasil, pode ser aproximado de seu uso pelo pensamento conservador alemão daquela mesma quadra histórica. Kracauer, em sua crítica contemporânea, formulou-o com agudeza, pondo em destaque o caráter romântico da concepção de "povo" e sua oposição às doutrinas liberais (cf. Kracauer, 1977 [1931]).

8 Em que medida Sérgio Buarque é tributário, em sua compreensão da questão das elites, de Pareto, Mosca e Michels, permanece em aberto. Citado é somente Pareto (cf. Hollanda, 1936, p. 22).

9 Portanto, de caráter anti-intelectualista e, sobretudo, voluntarista. $\mathrm{O}$ anti-intelectualismo está bem presente nos capítulos finais de Raízes do Brasil, "Novos tempos" e "Nossa revolução"; por exemplo, Hollanda (1936, pp. 146-147), quando critica as concepções abstratas, as fórmulas e os conceitos, o absolutismo da razão etc., todos estes hostis à vida. $\mathrm{O}$ anti-intelectualismo andava de mãos dadas com a crítica à mecanização e a consequente defesa do orgânico, todos eles motivos presentes no livro de Sérgio Buarque; ver Troeltsch (1922, p. 493). O anti-intelectualismo de Sérgio Buarque de Holanda em Raízes do Brasil é assinalado por Dias (2008, pp. 331, 338).

10 Também segundo um topos recorrente desde, pelo menos, a filosofia da contrarrevolução.

$11 \mathrm{Na}$ continuação desse aforismo, Nietzsche contrapõe Kant precisamente a Goethe, sugerindo assim que em Goethe teríamos uma afirmação, e não negação da vida. $\mathrm{O}$ vitalismo goetheano está, assim, presente no aforismo de Nietzsche, o mesmo vitalismo que decerto impressionava Sérgio Buarque de Holanda.

12 Na mesma direção vai a afirmação, amplamente favorável à oligarquia imperial, no terceiro capítulo do li- vro (cf. Hollanda, 1936, pp. 44-45). Em 1920, Sérgio afirmava ser a monarquia "o regime ao qual devemos setenta anos de prosperidade", no mesmo movimento em que condenava "a importação do regime republicano" (Holanda, 1996 [1920], pp. 42-43). Chamo com isso a atenção para o fato de que muitos dos temas e problemas discutidos no livro de 1936 podem e devem ser rastreados nos escritos de Sérgio a partir de 1920 - uma tarefa que foge ao escopo deste artigo. Ver Eugênio (2008).

13 Este é outro motivo recorrente do conservadorismo. Ver Mannheim (1984 [1925]), Kracauer (1977 [1931]) e Nisbet (1952).

14 No capítulo seguinte, Sérgio afirma, com relação ao período colonial: "Nossa sociedade era, assim, um organismo amorfo e invertebrado [...]" (Hollanda, 1936, p. 32). Posteriormente, "mundo sem forma" (Idem, p. 108). E outras formulaçōes de sentido similar.

15 Já em artigo de 1920, Sérgio Buarque desenvolvia argumento similar; ver Holanda (1996 [1920], pp. 42, 45).

16 Uma anomalia: é impossível não lembrar do final de Os donos do poder, onde se fala, pela letra de Toynbee, de uma "monstruosidade social" (Faoro, 1958, p. 271).

17 Pois, embora de maneira mais sofisticada, o argumento desenvolvido por Sérgio neste ponto pode ser visto como uma variação da fórmula "país legal - país real". Ver Hollanda (1936, pp. 124-131), onde se aponta para a "distância entre o elemento 'consciente' e a massa brasileira”. Isso é, no campo de problematização de Raízes do Brasil, formulado recorrentemente segundo a fórmula do nosso "horror à realidade". Ver a tomada de posição com relação a Alberto Torres (Hollanda, 1936, pp. 145ss, e 157). Note-se que Sérgio concorda com o diagnóstico da disjunção de "nação e vida política”, discordando apenas, ao que parece, da terapia proposta. Cf. também Holanda (2006 [1935a], pp. 406-407), e para uma visão geral do problema, ver Lamounier (1977).

18 A questão não é simples. Em discurso de 8 de setembro de 1933, o líder nacional afirmava: "É fato incontroverso [...] a decadência em que caiu a concepção de democracia liberal e individualista e a preponderância dos governos de autoridade [...]" (Vargas apud Faoro, 2001, p. 781). Parece-me que ainda está por ser feita uma aproximação mais detalhada de Raízes do Brasil a seu contexto político-social mais imediato.

19 Transladando o argumento do registro coletivo para o individual, cabe lembrar que orientar a conduta pela apreciação do outro é o que há de mais distante da- 
quele indivíduo, tematizado já no início do livro, que se basta a si mesmo

20 Tanto quanto acompanho a discussão acerca de Raízes do Brasil, quem mais se aproxima desta minha argumentação é Wegner (2006, pp. 353-356).

21 Monteiro (2008, p. 360) não deixa de assinalar, embora em meu juízo de modo reticente, o problema. Sem me alongar no debate com a bibliografia que comenta as alterações, gostaria de marcar posição, afirmando que o principal das alterações não é um aprofundamento histórico, ou o testemunho de um trabalho de historiador - no qual Sérgio haveria se tornado -, mas sim o problema político. O aprofundamento histórico é funcional para ensombrecer a dimensão política, assim como o discurso acerca da conversão em historiador é funcional para sombrear o problema político.

22 "Com a redemocratização do país em 1945, uma complexa teia de atitudes e interesses contribuiu para selar as descontinuidades intelectuais produzidas pelo Estado Novo, dificultando ainda mais a apreensão e a crítica do pensamento autoritário das décadas anteriores", afirma Lamounier (1977, p. 347). Tanto mais complexo é o caso de Raízes do Brasil, que permanece em posição comparativamente mais ambígua como expressão do pensamento autoritário daquela quadra (ambiguidade essa reforçada pelas alterações entre as edições de 1936 e 1948). Ele é, digamos, tanto um crítico da Primeira República - como os visados por Lamounier em seu estudo -, como um crítico dos críticos, pretendendo uma crítica da crítica crítica. Contudo, é patente a sua nostalgia pelo Império, que compartilha com alguns dos "críticos autoritários". Embora Sergio Buarque esteja em princípio para além do recorte do "pensamento autoritário formado a partir da Primeira República" trabalhado por Lamounier, pois, à diferença do que procuro argumentar, sua simpatias autoritárias foram sendo progressivamente ocultadas pela história da recepção de Raízes do Brasil, parece-me evidente a sua proximidade a essa vertente. Para o livro de 1936 vale também a descrição seguinte: "O objetivo de persuadir as elites políticas e culturais da época é visível na própria estrutura narrativa, que invariavelmente se inicia com amplas reflexões histórico-sociológicas sobre a formação colonial do país, estende-se no diagnóstico do presente - no caso, a República Velha - e culmina na proposição de algum modelo alternativo de organização político-institucional" (Lamounier, 1977, p. 345). O ajuste necessário é considerar que, publicado após a Revolução de 1930, Raízes do Brasil já ganha perspectiva em face da nova situação política, já quase às portas do Estado Novo, de um lado, e sua proposição foi formulada de modo mais ambíguo, de outro. Como consequência, Sérgio Buarque permaneceu uma figura fora de esquadro no quadro dos críticos e ideólogos autoritários daquela situação.

23 Para evitar mal-entendidos: importa menos o que Nietzsche dizia e mais como era compreendido. No contexto, Nietzsche foi tomado como mentor de muito da crítica da cultura de cunho conservador. Ver Stern (1961), assim como Chaves (2008, pp. 400401). (Não tive acesso a Chaves, 2000). Em 1948, no imediato pós-guerra, Nietzsche estava bastante comprometido pelo uso (abuso) que lhe fez o nacional-socialismo, sendo portanto o expurgo funcional para o contexto de "redemocratização". Interessante sintoma, para indicar o contexto local, é o artigo de Antonio Candido de 1946, "O portador", que procura reabilitar Nietzsche de um uso político reacionário.

24 Uma das alternativas, naquela quadra histórica, é discutida por Sérgio Buarque em artigos de 1929 sobre a Polônia (cf. Holanda, 1988 [1929b]).

25 Cf. carta de R. Bopp a Sérgio Buarque, Hamburgo, dezembro de 1930 apud Carvalho (2003, p. 142).

26 Em entrevista, Sérgio Buarque de Holanda também afirmou, retrospectivamente, ter descartado a filosofia mística e o irracionalismo (Holanda, 1982, p. 5).

27 A presença do pensamento racista em Raízes do Brasil merece ainda investigação detalhada. Gostaria apenas de observar que a questão do racismo, de pontos de vista racistas, de higiene racial e temas similares é presente, embora não seja determinante, em variados momentos do livro e assumida positivamente pelo autor. Ao explanar sobre o fracasso da colonização holandesa, Sérgio Buarque mobiliza a opinião de "uma das maiores autoridades no assunto", o antropólogo, higienista racista e eugenista alemão Eugen Fischer (1874-1967), para justificar como "os europeus do norte são incompatíveis com as regióes tropicais" (Hollanda, 1936, pp. 37-38). Em outro momento, na nota polêmica contra Oliveira Vianna, retirada das ediçōes posteriores do livro ("nota B": Idem, pp. 166169), Sérgio contesta a proximidade de Oliveira Vianna com discípulos de Le Play justamente porque eles todos acentuariam "os caracteres étnicos antes como efeito do que como causa", sugerindo assim que o entendimento correto deveria acentuar a causalidade do "caractere étnico". Sérgio contesta que o "fator étnico" seja de importância secundária, ao mesmo tempo em que critica de forma decidida as pretençôes "ariani- 
zantes" de Oliveira Vianna. Em outro momento, Sérgio cita Hans Günther (1891-1968), antropólogo e eugenista alemão, um dos mentores da política racial nacional-socialista, quando se trata de justificar a ausência de "orgulho da raça" entre os nossos colonizadores portugueses: isso se deve, segundo a explicação de Günther retomada por Sérgio, ao fato de os portugueses, mesmo diante dos espanhois, "ostentarem um contingente maior de sangue negro" (Hollanda, 1936, pp. 27-28). Além disso, podemos detectar a presença de ideias-feitas acerca dos "semitas", como no passo: "A fisionomia mercantil, quase semita, dessa colonização [...]" (Idem, p. 79). Carvalho (2003, pp. 26-27, 29-30, 168-170) chama a atenção para o entendimento de "raçă" nos escritos de Sérgio Buarque que vão até Raízes do Brasil.

28 A título de exemplo, basta mencionar as "formas de vida", que aparecem no parágrafo de abertura do livro em 1936, e em 1948 tornam-se "formas de convívio". Como se sabe, "formas de vida" é tradução de "Lebensformen", termo recorrente nas vertentes vitalistas e irracionalistas alemãs e que pretende uma totalização de cultura, sociedade e personalidade (cf. Hillmann, 1994, p. 474). O uso que Sérgio Buarque faz do vocábulo é claramente devedor do contexto intelectual alemão. Esse é apenas um exemplo, entre inúmeros, da questão; o aspecto que deve ser posto em evidência é que os termos ganham peso e importância justamente por Sérgio Buarque ter se dado ao trabalho de os alterar entre uma edição e outra. A alteração dos termos revela precisamente o desejo de se afastar do contexto nebuloso dos anos do Entreguerras, no qual todos os gatos pareciam pardos. Os acontecimentos ao longo dos anos de 1930, na Europa, tornaram mais complexos os usos, abusos e mal-usos terminológicos.

29 Referindo-me a Troeltsch, Mannheim, Kracauer e Horkheimer, estou intencionalmente utilizando textos do contexto imediato dos anos de 1920, com cuja letra, ou espírito (porque bastante difuso), Sergio Buarque decerto teve contato em sua estadia na Alemanha.

30 Sobre o vitalismo em Sérgio Buarque, ver Eugênio (2008).

31 No artigo citado desenvolvo, em conjunto com A. Goldfeder, uma argumentação mais ampla a esse respeito, da qual reproduzo aqui apenas uma das conclusões.

32 Outras passagens, que testemunham a mesma perspectiva: "criações engenhosas do espírito, destacadas do mundo e contrárias a ele"; "antagonismo entre o Espírito e a Vida"; "viver pelo espírito e não pelo sangue” (Hollanda, 1936, pp. 6, 9, 126).
33 Ver também o depoimento de Sérgo Buarque citado em Castro (2008, p. 203).

34 Embora esse não seja o fio condutor dos argumentos e preocupaçōes dos autores, surge com nitidez nos estudos de Prado (2010) e Sevcenko (1992). Para o caso alemão, ver Ringer, (1987, pp. 300ss).

35 Esse é um outro tema já presente nos escritos do autor nos anos de 1920, recorrente na forma da crítica ao americanismo, mas não só (ver Holanda, 2008 [1921]).

\section{BIBLIOGRAFIA}

BANDEIRA, Manuel. (1988 [1931]), "Introdução", in F. A. Barbosa (org.), Raizes de Sérgio Buarque de Holanda, Rio de Janeiro, Rocco, pp. 291-293.

BOTELHO, André. (2009), "Pasado futuro de los ensayos de interpretación del Brasil”. Prismas, 13: 183-196.

BRANDÃO, Gildo M. (2007), Linhagens do pensamento politico brasileiro. São Paulo, Hucitec.

CANDIDO, Antonio. (2004 [1946]), "O portador”, in _ O observador literário, 3 ed. rev., Rio de Janeiro, Ouro sobre Azul, pp. 79-87.

. (2006 [1967]), "O significado de Raizes do Brasil", in S. B. de Holanda, Raizes do Brasil, São Paulo, Cia. das Letras, pp. 235-250. . (1988 [1982]), "Introdução", in F. A. Barbosa (org.), Raizes de Sérgio Buarque de Holanda, Rio de Janeiro, Rocco, pp. 119-129. . (2006 [1986]) "Post-scriptum", in S. B. de Holanda, Raízes do Brasil, São Paulo, Cia. das Letras, pp. 251-252.

. (2008 [1998]), "A visão política de Sérgio Buarque de Holanda", in P. M. Monteiro e J. K. Eugênio (orgs.), Sérgio Buarque de Holanda: perspectivas, Campinas/Rio de Janeiro, Unicamp/Eduerj, pp. 29-36.

CASTRO, Conrado P. (2008), "Motivos ibéricos, pretextos literários", in P. M. Monteiro e J. K. Eugênio (orgs.), Sérgio Buarque de Holanda: perspectivas, Campinas/Rio de Janeiro, Unicamp/Eduerj, pp. 181-208.

CARVALHO, Marcus V. C. (2003), Outros lados: 
Sérgio Buarque de Holanda, crítica literária, história e politica (1920-1940). Campinas, tese de doutorado, Unicamp.

CHAVES, Hernani. (2000), "Raizes do Brasil e Nietzsche". Cult, 37.

. (2008), "O historicismo de Nietzsche, segundo Sérgio Buarque de Holanda”, in P. M. Monteiro e J. K. Eugênio (orgs.), Sérgio Buarque de Holanda: perspectivas, Campinas/Rio de Janeiro, Unicamp/Eduerj, pp. 397-412.

DIAS, Maria O. S. (2008), "Negação das negações", in P. M. Monteiro e J. K. Eugênio (orgs.), Sérgio Buarque de Holanda: perspectivas, Campinas/Rio de Janeiro, Unicamp/Eduerj, pp. 317-348.

EUGÊNIO, João K. (2008), "Um horizonte de autenticidade", in P. M. Monteiro e J. K. Eugênio (orgs.), Sérgio Buarque de Holanda: perspectivas, Campinas/Rio de Janeiro, Unicamp/ Eduerj, pp. 425- 459.

FAORO, Raymundo. (1958), Os donos do poder. Porto Alegre, Globo. . (2001), Os donos do poder. 3 ed. rev. São Paulo, Globo.

GOLDFEDER, André e Waizbort, Leopoldo. (2009), "Sobre os 'tipos' em Raízes do Brasil'. Revista do Instituto de Estudos Brasileiros, 49: 13-36.

HILLMANN, Karl-Heiz. (1994), Wörterbuch der Soziologie. 4. ed. Revista. Stuttgart, Kröner.

HOLANDA, Sérgio Buarque de. (1996 [1920]), "Ariel" in O espirito e a letra, São Paulo, Cia. das Letras, vol. 1, pp. 42-46. (2008 [1921]), "O home-máquina", in P. M. Monteiro e J. K. Eugênio (orgs.), Sérgio Buarque de Holanda: perspectivas, Campinas/Rio de Janeiro, Unicamp/Eduerj, pp. 559562.

cial", in (1996 [1924]), "Um homem essenPaulo, Cia. das Letras, vol. 1, pp. 179-185. . (1996 [1929a]), "Indicação", in , O espirito e a letra, São Paulo, Cia. das Letras, vol. 1, pp. 246-247. . (1988 [1929b]), "O Marechal Pilsudski e os vícios do parlamentarismo polonês" e "Um país que ressurge", in F. A. Barbosa (org.),
Raizes de Sérgio Buarque de Holanda, Rio de Janeiro, Rocco, pp. 157-169.

. (2006 [1935a]), "Corpo e alma do Brasil", in , Raízes do Brasil, São Paulo, Cia. das Letras, pp. 399-420.

(1988 [1935b]), "O Estado totalitário”, in F. A. Barbosa (org.), Raizes de Sérgio Buarque de Holanda, Rio de Janeiro, Rocco, pp. 298-301.

. (1936), Raizes do Brasil. Rio de Janeiro, José Olympio.

(1948), Raizes do Brasil. 2. Ed., revista e ampliada. Rio de Janeiro, José Olympio.

(1978), Cobra de vidro. 2 ed. São Paulo, Perspectiva/Secretaria de Cultura.

(1979), Tentativas de mitologia. São

Paulo, Perspectiva.

. (1982), "An interview with Sergio Buarque de Holanda". The Hispanic American Historical Review, 62 (1): 3-17.

. (2006), Raízes do Brasil. São Paulo, Cia. das Letras.

HORKHEIMER, Max. (1990 [1926]), “Einführung in die Philosophie der Gegenwart (Vorlesung)", in Gesammelte Schriften, Frankfurt, M. Fischer, vol. 10, pp. 169-333.

KORFF, H. A. (1923), Geist der Goethezeit. Leipzig, J. J. Weber.

KRACAUER, Sigfried. (1977 [1931]), "Aufruhr der Mittelschichten", in , Das Ornament der Masse, Frankfurt a.M., Suhrkamp, pp. 81-105.

LAMOUNIER, Bolivar. (1977), "Formação de um pensamento político autoritário na Primeira República: uma interpretação", in B. Fausto (org.), História geral da civilização brasileira O Brasil republicano, São Paulo, Difel, t. 3, vol. 2, pp. 343-374.

MANNHEIM, Karl. (1964 [1924]), "Historismus", in ,Wissenssoziologie, Berlim, Luchterhand, pp. 246-307.

(1984 [1925]), Konservatismus. Ein Beitrag zur Soziologie des Wissens. Frankfurt a.M., Suhrkamp.

Cohen.
. (1929), Ideologie und Utopie. Bonn, F. 
MONTEIRO, Pedro M. (2008), "Uma tragédia familiar", in P. M. Monteiro e J. K. Eugênio (orgs.), Sérgio Buarque de Holanda: perspectivas, Campinas/Rio de Janeiro, Unicamp/Eduerj, pp. 349-361.

NIETZSCHE, Friedrich. (1988 [1873-1876]), Unzeitgemaesse Betrachtungen, in G. Colli e M. Montinari (orgs.), Saemtliche Werke. Kritische Studienausgabe, 2 ed. rev., München, DTV/de Gruyter, vol. 1, pp. 157-510. . (1988 [1888a]), Der Antichrist, in G.

Colli e M. Montinari (orgs.), Saemtliche Werke. Kritische Studienausgabe, 2 ed. rev., München, DTV/de Gruyter, vol. 6, pp. 165-254. (1988 [1888b]), Goetzen-Daemme-

rung, in G. Colli e M. Montinari (orgs.), Saemtliche Werke. Kritische Studienausgabe, 2 ed. rev., München, DTV/de Gruyter, vol. 6, pp. 55-161.

NISBET, Robert A. (1952), "Conservatism and sociology”. The American Journal of Sociology, 58 (2): $167-175$.

PRADO, Antonio A. (2010), Itinerário de uma falsa vanguarda. São Paulo, Editora 34.

RINGER, Fritz K. (1987), Die Gelehrten. München, DTV.

SEVCENKO, Nicolau. (1992), Orfeu extático na metrópole. São Paulo, Cia. das Letras.

STERN, Fritz. (1961), The politics of cultural despair: a study in the rise of Gemanic ideology. Berkeley, University of California Press.

TROELTSCH, Ernst. (1922), Der Historismus und seine Probleme. (Gesammelte Schriften, vol. 3). Tübingen, J. C. B. Mohr (Paul Siebeck).

VECCHI, Roberto. (2008), "Contrapontos à brasileira”, in P. M. Monteiro e J. K. Eugênio (orgs.), Sérgio Buarque de Holanda: perspectivas. Campinas/Rio de Janeiro, Unicamp/Eduerj, pp. 363-384.

WAIZBORT, Leopoldo. (2000), As aventuras de Georg Simmel. São Paulo, Editora 34.

WEGNER, Robert. (2006), "Um ensaio entre o passado e o futuro", in S. B. de Holanda, Raizes do Brasil, São Paulo, Cia. das Letras, pp. 335-364. 


\section{O MAL-ENTENDIDO DA DEMOCRACIA: SERGIO BUARQUE DE HOLLANDA, RAIZES DO BRASIL, 1936}

\section{Leopoldo Waizbort}

Palavras-chave: Sérgio Buarque de Holanda; Democracia; Raízes do Brasil; Personalismo.

$\mathrm{O}$ artigo procura discutir e esclarecer tópicos do argumento político desenvolvido por Sérgio Buarque de Holanda em Raizes do Brasil. Para tanto, retoma algumas das problematizaçōes presentes na edição de 1936, que foram posteriormente alteradas ou expurgadas, no intuito de reconstruir o conteúdo político do argumento e situar a argumentação em seu contexto de época, assim como apontar os vínculos estabelecidos com outros autores e ideias.

\section{THE MISUNDERSTANDING OF DEMOCRACY: SERGIO BUARQUE DE HOLLANDA, RAIZES DO BRASIL, 1936}

\section{Leopoldo Waizbort}

Keywords: Sérgio Buarque de Holanda; Democracy, Roots of Brazil; Personalism.

The article seeks to discuss and clarify topics on the political argument developed by Sergio Buarque de Holanda in Roots of Brazil. For this purpose, it returns to some of the problematization found in the 1936 publication, which was later either modified or purged in order to reconstruct the political content of the argument and to situate such argumentation in the context of its time, as well as to point out established ties with other authors and ideas.

\section{LE MALENTENDU DE LA DÉMOCRATIE: SERGIO BUARQUE DE HOLANDA, RACINES DU BRÉSIL, 1936}

\section{Leopoldo Waizbort}

Mots-clés: Sérgio Buarque de Holanda; Démocratie; Racines du Brésil; Personnalisme.

Cet article a pour but de discuter et de clarifier des questions à propos de l'argument politique développé par Sergio Buarque de Holanda dans son livre Racines du Brésil. Certaines des problématisations présentes dans l'édition de 1936, qui ont ensuite été modifiées ou éliminées afin de reconstruire le contenu politique de l'argumentation et de situer l'argument dans le contexte de son époque, sont rediscutées. Les liens établis avec d'autres auteurs et idées sont également indiqués. 